\title{
Studies of trans- and cis-xylomollin molecular structures using molecular dynamics simulations
}

\author{
Radia Mahboub \\ Department of Chemistry, Faculty of Sciences, University of Tlemcen, \\ B.P. 119, Tlemcen, 13000 , Algeria \\ E-mail address: radiamahboub@yahoo.com
}

\begin{abstract}
The present work describes the comparative study of the trans- and the cis-xylomollin structures. We have determined the two bridgehead $\mathrm{H}_{5}$ and $\mathrm{H}_{9}$ configurations using simulation calculations for both trans- and cis- distereoisomers. Molecular Dynamic (MD) simulations of the trans- and cis- xylomollin were performed with an efficient program. The geometries, interaction energies, bonds, angles, and the Van der Waals (VDW) interactions were carried out in solution and gas phases. This comparative study shows that the trans-xylomollin acquires the high configuration energy under the AMBER field using MD method. This molecule reaches its high stable configuration state in solution environment. Our MD simulation results are goods and in agreement with those of literature.
\end{abstract}

\section{Keywords:}

xylomollin; trans-fused iridoid; modeling structure; molecular dynamic

\section{INTRODUCTION}

Heterocyclic molecules are the rings composed of both carbon and one or more heteroatoms. The heteroatom of heterocyclic molecules is generally oxygen, sulfur, or nitrogen, with the latter being particularly common in biochemical systems. Heterocyclic with relatively simple structures are pyrrole (5-membered) and indole (6-membered carbon ring). Rings can fuse with other rings on an edge to give polycyclic compounds. Rings can also fuse on a "corner" such that one atom (always carbon) has two bonds going to one ring and two to another. Such compounds are termed spiro and are important in a number of natural products. They can be unsaturated or aromatic heterocyclic or saturated heterocyclic. Alkaloids, chromenes, coumarins, flavonoids, xanthones are some examples.

These compounds must be ecologically non-toxic for human. So, the author has classified then into two classes (table 1) [1]. Chemicals derived from the first classes are vital for the preservation and the protection of life processes, and have also theirs toxicological, pharmacological and ecological importance. The second classes are used in modern industry and medicine. 
Table 1. Chemical classes of biologically active compounds [1]

\begin{tabular}{|c|c|}
\hline First Classes & Second Classes \\
\hline Aliphatic alcohol, Acids & Gums \\
\hline Amino acids, Alkaloids & Glues \\
\hline Carbohydrates, Carotenoids, Hydrocarbons & Alkaloids \\
\hline Fatty Acids and Polyunsaturated Fatty Acids & Saponins \\
\hline Lipids, Pheromones, Phorbol esters, Phenolics & \\
\hline Steroids, Triterpenes, Glucosides & \\
\hline Tannins & \\
\hline
\end{tabular}

Iridoids compose a class of natural compounds which have various biological activities such as antiviral [2], anti-allergic, anti-anaphylactic, analgesic [3], antioxidant [4, 5], antimicrobial, antirheumatic, laxative, hypotensive, sedative, antitumor $[2,6]$, immunostimulant $[7,9]$, antimicrobial $[10,11]$ and hepatotoxic [13-15]. Others show radical scavenging activity against DPPH, antioxidant activity against $\beta$-carotene [12] and significant inhibition of UVB-induced: Activator Protein-1 activity in cell culture [16, 17].

Furthermore, the Xylomollin 1 belongs to the first classes. Our interest of this molecule becomes for its trans-fused iridoid terpene structure which has multiply applications in pharmacological.

In the present work, we describe and characterize the molecular structure of trans- and cis- xylomollin by MD simulation using AMBER as the force fields. We discuss the computational chemistry results of the two diastereoisomer compounds then we compare their two calculations results with the coupling constant effects.

In section 2, we report the stereochemistry for each compound (trans- and cis-) using the coupling constants.

In section 3, we describe the materials and methods used in this study. In the next section, we have detailed the molecular calculations: i) geometry optimization, and ii) dynamic simulations. In the second part, we discuss the evolution of: i) energies, ii) dihedrals angles, and iii) geometry optimization in both vacuum and water environments. We present the calculation results obtained for the two compounds by Molecular dynamics, and then we compare all these results. In the last section, we give the conclusion.

\section{STRUCTURE OF XYLOMOLLIN}

Xylomollin 1 is the first natural heterocyclic compound of a trans-fused secoiridoid hemiacetal acetal. From natural source, its can be isolated in only small amounts and it represents one example of the naturally occurring cyclopentanomoterpenes.

Xylomollin 1 is the $(1 \mathrm{R}, 4 \mathrm{a} \alpha, 8 \mathrm{a} \beta)$-hexahydro-1 $\alpha$-hydroxy-3$\beta$-methoxy-8$\beta$-methyl-6oxo-1H,3H-pyrano[3,4-c]pyran-4 $\alpha$-carboxylic acid methyl ester. 

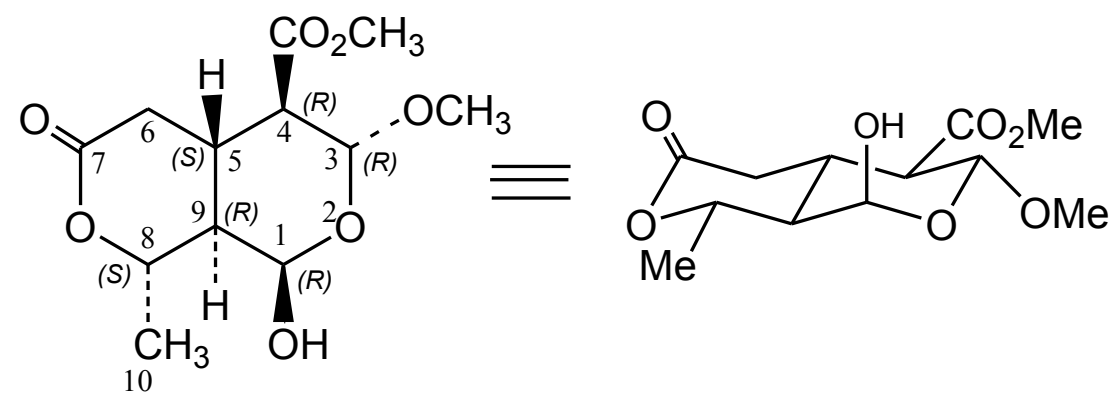

1

$(1 R, 3 R, 4 R, 4 \mathrm{a} S, 8 S, 8 \mathrm{a} R)$-methyl 1-hydroxy-3-methoxy-8-methyl-6-oxo-octahydropyrano[3,4-c]pyran-4carboxylate

Fig. 1. Structure of Xylomollin.

The authors were fascinated by the structure of xylomollin. For it synthesis, they have suggested that a cis-bicyclo[3.3.0]octane can be transformed into the trans-fused natural product. The transformation occurs by the inversion of stereochemistry at one of the bridgehead carbon [18]. Previously, Nakane and all have partially synthesized the xyllomolin and have found that the stereochemical control is realized by an inversion of configuration for one length chain [19].

In literature, we found some structures related to known iridoids [20]. Compound 2 has the $8(S)$-secoiridoids unlike kingiside 3 and sarracenin 4 have the $8(R)$ configuration. The two synthetics (-)-1-OMe-2 and its C-3 epimer 5 were prepared from (-)-loganin 6, and have cis- configurations (figure 2). The (-)-1-OMe-2 complies with a gauche relationship of the bridgehead hydrogens in a cis-decalin system $\left({ }^{3} J_{\mathrm{H} 5 \mathrm{H} 9}\right.$ values: $4.8 \mathrm{~Hz}$ and $\left.9.4 \mathrm{~Hz}\right)$ [21]. So, with the ${ }^{3} J_{\mathrm{H} 5 \mathrm{H} 9}$ value of $10 \mathrm{~Hz}$ found in 1 is too large for a cis-fused decalin system; the xylomollin's structure is related to: $5(S), 8(S), 9(R)$-secoiridoid. The all trans- diaxial orientation of the methine hydrogens is more regular with the reported ${ }^{1} \mathrm{H}$ NMR coupling constant data [22].<smiles>CO[C@H]1O[C@H](O)[C@H]2[C@@H](C)OC(=O)C[C@H]2[C@H]1C(C)=O</smiles>

2<smiles>CC(=O)C1=CO[C@@H](O)[C@@H]2C(C)OC(=O)CC12</smiles>

3<smiles>COC(=O)C1=COC2OC3O[C@H](C)[C@H](C1)[C@H]23</smiles>

4

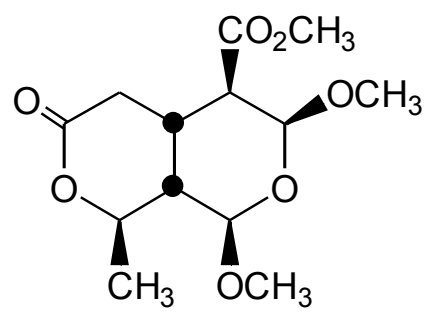

5<smiles>CC(=O)C1=CO[C@@H](O[AlH2])[C@@H]2[C@@H]1C[C@H](O)[C@@H]2C</smiles>

6

Fig. 2. Structures of secoiridoids. 
In the xylomollin 1 , the two bridgeheads $\mathrm{H}_{5}$ and $\mathrm{H}_{9}$ have trans-configuration [23]. The $\mathrm{H}_{5}$ was shown to possess a $\beta$-orientation with a large coupling constant $\left(\delta_{\mathrm{H}}=3 \mathrm{ppm}\right.$, dddd, $\left.1 \mathrm{H}, \mathrm{J}=10 \mathrm{~Hz}, \mathrm{H}_{5}\right)[24]$, the second one was also proposed to have an $\alpha$-orientation $\left(\delta_{\mathrm{H}}=1.75\right.$ ppm, ddd, $1 \mathrm{H}, \mathrm{J}=10 \mathrm{~Hz}, \mathrm{H}_{9}$ ) when compared to the literature report [25, 26]. In the cis-fused iridoid, authors have shown that the NOE cross peaks between $\mathrm{H}_{5}$ and $\mathrm{H}_{9}$ provided the same orientation for the two protons with a small coupling constant in the ${ }^{1} \mathrm{H}-\mathrm{NMR}$ spectrum (4 $\mathrm{Hz}$ ) [27]. Therefore, the two iridoids have distinct configurations. So, this involve that the compound 1 has trans-configuration.

In order to confirm the stereochemistry of compound 1, we have studied the two molecules: trans- and cis- xylomollin by comparing their calculation data. For this, we have using the Molecular Dynamic simulations at constant temperature both in vacuum and in water.

\section{MATERIALS AND METHODS}

Molecular Dynamics (MD) is a talented method used to model a simulation of macroscopic systems involving a few molecules. Today, MD tends to become an alternative to experiments in order to provide complements geometry, structural and thermodynamic characteristics. Molecular simulation provides an intermediate method between experiments and classical models. It gives useful predictions to understand the relation property-chemical structure.

All MD simulations were performed with AMBER force field using conjugate gradient algorithm. In vacuum, the system was simulated using Molecular Dynamics with $0.0001 \mathrm{ps}$ step. Temperature was kept constant at $300 \mathrm{~K}$. The starting temperature was taken at $100 \mathrm{~K}$ and the step at $20 \mathrm{~K}$. In water, simulations, the system was placed in a box $(20 \times 20$ x $20 \AA$ ) containing one molecule of Xylomollin (trans- or cis-) and 246 water molecules and cut-off $4 \AA$. Optimization of the molecule was realized in periodic boundary conditions (PBC). The compounds were solvated by added water molecules. The systems were first energy minimized steps with the conjugate gradient algorithm. Then, the position-restrained MD simulation was run $0.5 \mathrm{ps}$.
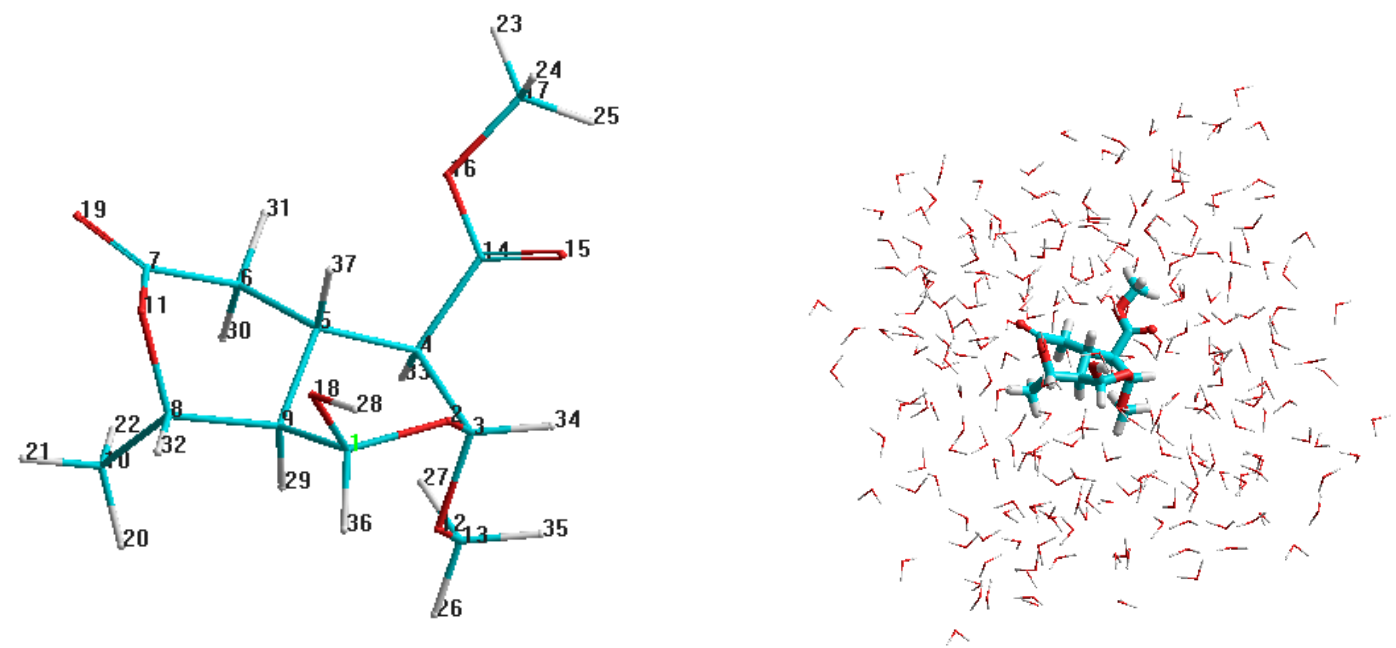

Fig. 3. Geometry structure of trans-xyllomolin: (a) in vacuum, (b) in water. 


\section{RESULTS AND DISCUSSIONS}

\section{1. Geometry optimization}

Trans- (gauche) conformation of the trans-xylomollin structure is confirmed by the dihedral angle $\left(\mathrm{H}_{37}-\mathrm{C}_{5}-\mathrm{C}_{9}-\mathrm{H}_{29}\right)$ and the distance bonds. In the isolated and the solvated compound, this torsion angle does not change. So, we have obtained an anhedral angle value of $-164.135^{\circ}$ (table 2a). This situation is due of the strong Van der Waals collisions in transxylomollin or between trans-xylomollin and water under AMBER.

For the cis-xylomollin, the conformation is verified by the same parameters. In that case, we have found that the dihedral angle $\left(\mathrm{H}_{37}-\mathrm{C}_{5}-\mathrm{C}_{9}-\mathrm{H}_{29}\right)$ is an anhedral one and its value fluctuate around $-40^{\circ}$ (table $2 \mathrm{~b}$ ).

Table 2a. Structural properties of trans-xylomollin with AMBER.

\begin{tabular}{|c|c|c|c|c|c|c|c|c|c|c|c|c|c|c|c|}
\hline \multicolumn{16}{|c|}{ trans-xylomollin } \\
\hline \multicolumn{8}{|c|}{ Isolated } & \multicolumn{8}{|c|}{ Solvated } \\
\hline Bond & $\mathrm{D}(\AA)$ & Angle & $\theta\left({ }^{\circ}\right)$ & Dihedral & $\Phi\left(^{\circ}\right)$ & $\Delta$ & $\Delta(\AA)$ & Bond & $\mathrm{D}(\AA)$ & Angle & $\theta\left({ }^{\circ}\right)$ & Dihedral & $\Phi\left(^{\circ}\right)$ & $\Delta$ & $\Delta(\AA)$ \\
\hline $1-2$ & 1.424 & $4-5-9$ & 107.551 & $4-5-9-1$ & 68.867 & $37-29$ & 3.014 & $1-2$ & 1.424 & $4-5-9$ & 107.552 & $4-5-9-1$ & 68.865 & $37-29$ & 3.014 \\
\hline $2-3$ & 1.420 & $6-5-9$ & 110.206 & $6-5-9-8$ & -39.914 & $37-31$ & 2.464 & $2-3$ & 1.420 & $6-5-9$ & 110.206 & $6-5-9-8$ & -39.943 & $37-31$ & 2.464 \\
\hline $3-4$ & 1.548 & $6-5-37$ & 107.707 & $37-5-9-29$ & -164.435 & $37-30$ & 3.044 & $3-4$ & 1.548 & $6-5-37$ & 107.707 & $37-5-9-29$ & -164.437 & $37-30$ & 3.044 \\
\hline $4-5$ & 1.536 & $8-9-5$ & 113.742 & & & $37-36$ & 3.644 & $4-5$ & 1.536 & $8-9-5$ & 113.742 & & & $37-36$ & 3.644 \\
\hline $5-6$ & 1.529 & $1-9-5$ & 106.76 & & & $37-33$ & 3.026 & $5-6$ & 1.529 & $1-9-5$ & 106.76 & & & $37-33$ & 3.026 \\
\hline $6-7$ & 1.524 & $8-9-29$ & 106.726 & & & $37-34$ & 3.574 & $6-7$ & 1.524 & $8-9-29$ & 106.726 & & & $37-34$ & 3.574 \\
\hline $7-11$ & 1.354 & & & & & $29-30$ & 2.688 & $7-11$ & 1.354 & & & & & $29-30$ & 2.688 \\
\hline $11-8$ & 1.418 & & & & & $29-36$ & 2.332 & $11-8$ & 1.418 & & & & & $29-36$ & 2.332 \\
\hline $8-9$ & 1.547 & & & & & $29-32$ & 2.815 & $8-9$ & 1.547 & & & & & $29-32$ & 2.815 \\
\hline $9-1$ & 1.540 & & & & & $29-31$ & 3.821 & $9-1$ & 1.540 & & & & & $29-31$ & 3.821 \\
\hline $8-10$ & 1.534 & & & & & $29-34$ & 3.797 & $8-10$ & 1.534 & & & & & $29-34$ & 3.797 \\
\hline $3-12$ & 1.422 & & & & & $29-33$ & 2.507 & $3-12$ & 1.422 & & & & & $29-33$ & 2.507 \\
\hline $12-13$ & 1.418 & & & & & & & $12-13$ & 1.418 & & & & & & \\
\hline $4-14$ & 1.528 & & & & & & & $4-14$ & 1.528 & & & & & & \\
\hline 14-15 & 1.230 & & & & & & & $14-15$ & 1.230 & & & & & & \\
\hline $14-16$ & 1.355 & & & & & & & 14-16 & 1.355 & & & & & & \\
\hline 16-17 & 1.414 & & & & & & & $16-17$ & 1.414 & & & & & & \\
\hline $1-18$ & 1.412 & & & & & & & $1-18$ & 1.412 & & & & & & \\
\hline $7-19$ & 1.229 & & & & & & & $7-19$ & 1.229 & & & & & & \\
\hline
\end{tabular}

Table 2b. Structural properties of cis-xylomollin with AMBER.

\begin{tabular}{|c|c|c|c|c|c|c|c|c|c|c|c|c|c|c|c|}
\hline \multicolumn{16}{|c|}{ cis-xylomollin } \\
\hline \multicolumn{8}{|c|}{ Isolated } & \multicolumn{8}{|c|}{ Solvated } \\
\hline Bond & $\mathrm{D}(\AA)$ & Angle & $\Theta\left({ }^{\circ}\right)$ & Dihedral & $\Phi\left({ }^{\circ}\right)$ & $\Delta$ & $\Delta(\AA)$ & Bond & $\mathrm{D}(\AA)$ & Angle & $\Theta\left({ }^{\circ}\right)$ & Dihedral & $\Phi\left({ }^{\circ}\right)$ & $\Delta$ & $\Delta(\AA)$ \\
\hline $1-2$ & 1.418 & $4-5-9$ & 112.998 & $4-5-9-1$ & -41.190 & $37-29$ & 2.300 & $1-2$ & 1.418 & $4-5-9$ & 113.037 & $4-5-9-1$ & -41.058 & $37-29$ & 2.299 \\
\hline $2-3$ & 1.417 & $6-5-9$ & 109.897 & $6-5-9-8$ & -41.985 & $37-31$ & 2.466 & $2-3$ & 1.417 & $6-5-9$ & 109.966 & $6-5-9-8$ & -41.781 & $37-31$ & 2.465 \\
\hline $3-4$ & 1.537 & $6-5-37$ & 105.678 & $37-5-9-29$ & -42.679 & $37-30$ & 3.031 & $3-4$ & 1.536 & $6-5-37$ & 105.628 & $37-5-9-29$ & -42.524 & $37-30$ & 3.030 \\
\hline $4-5$ & 1.537 & $8-9-5$ & 111.714 & & & $37-36$ & 3.945 & $4-5$ & 1.537 & $8-9-5$ & 111.707 & & & $37-36$ & 3.945 \\
\hline $5-6$ & 1.531 & $1-9-5$ & 111.698 & & & $37-33$ & 2.526 & $5-6$ & 1.531 & $1-9-5$ & 111.724 & & & $37-33$ & 2.528 \\
\hline $6-7$ & 1.522 & $8-9-29$ & 106.346 & & & $37-34$ & 4.228 & $6-7$ & 1.522 & $8-9-29$ & 106.349 & & & $37-34$ & 4.228 \\
\hline $7-11$ & 1.353 & & & & & $29-30$ & 3.783 & $7-11$ & 1.353 & & & & & $29-30$ & 3.785 \\
\hline 11-8 & 1.418 & & & & & $29-36$ & 3.043 & $11-8$ & 1.418 & & & & & $29-36$ & 3.043 \\
\hline $8-9$ & 1.556 & & & & & $29-32$ & 2.212 & $8-9$ & 1.556 & & & & & $29-32$ & 2.213 \\
\hline $9-1$ & 1.542 & & & & & $29-31$ & 4.230 & $9-1$ & 1.542 & & & & & $29-31$ & 4.229 \\
\hline $8-10$ & 1.537 & & & & & $29-34$ & 4.172 & $8-10$ & 1.537 & & & & & $29-34$ & 4.173 \\
\hline 3-12 & 1.422 & & & & & $29-33$ & 3.861 & 3-12 & 1.422 & & & & & $29-33$ & 3.864 \\
\hline $12-13$ & 1.422 & & & & & & & $12-13$ & 1.418 & & & & & & \\
\hline 4-14 & 1.533 & & & & & & & $4-14$ & 1.533 & & & & & & \\
\hline $14-15$ & 1.230 & & & & & & & 14-15 & 1.230 & & & & & & \\
\hline $14-16$ & 1.356 & & & & & & & 14-16 & 1.356 & & & & & & \\
\hline 16-17 & 1.424 & & & & & & & 16-17 & 1.414 & & & & & & \\
\hline 1-18 & 1.411 & & & & & & & $1-18$ & 1.411 & & & & & & \\
\hline $7-19$ & 1.229 & & & & & & & 7-19 & 1.229 & & & & & & \\
\hline
\end{tabular}

$\Delta:$ Non-Bonded Distances 
The geometry optimizations of trans- and cis- xylomollin are realized in vacuum and in water (in PBC with a 246 TIP3P water molecules); using AMBER as the force field. The results are given in tables 3. As consequence, the trans- molecule has higher energies (dihedral, Van der Waals (VDW) and total) than the cis- structure in both situations (vacuum and solution). The cis- molecule acquires inverse situation for the bond and the angle energies.

Table 3a. Geometry optimization properties of trans-xylomollin at $300 \mathrm{~K}$ with AMBER before MD simulations.

\begin{tabular}{|c|c|c|c|c|c|c|c|c|c|}
\hline \multirow[b]{2}{*}{ State } & \multicolumn{9}{|c|}{ Geometry } \\
\hline & $\begin{array}{c}\text { Bond } \\
(\mathrm{Kcal} / \mathrm{mol})\end{array}$ & $\begin{array}{c}\text { Angle } \\
(\mathrm{Kcal} / \mathrm{mol})\end{array}$ & $\begin{array}{c}\text { Dihedral } \\
(\mathrm{Kcal} / \mathrm{mol})\end{array}$ & $\begin{array}{c}\text { VDW } \\
(\mathrm{Kcal} / \mathrm{mol})\end{array}$ & $\begin{array}{c}\text { Stretch- } \\
\text { bend } \\
\text { (Kcal/mol) }\end{array}$ & $\begin{array}{c}\text { H-bond } \\
\text { (Kcal/mol) }\end{array}$ & $\begin{array}{l}\text { Electrostatic } \\
(\mathrm{Kcal} / \mathrm{mol})\end{array}$ & $\begin{array}{c}\text { Energy } \\
(\mathrm{Kcal} / \mathrm{mol})\end{array}$ & $\begin{array}{c}\text { Gradient } \\
\text { (Kcal/ } \\
\text { Å.mol) }\end{array}$ \\
\hline Isolated & 0.6607 & 3.5038 & 9.7106 & 3.4996 & - & -0.0002 & 0 & 17.3746 & 0.0869 \\
\hline Solvated & 0.6605 & 3.5034 & 9.7104 & 3.5079 & - & -0.0002 & 0 & 17.3820 & 0.0870 \\
\hline
\end{tabular}

Table 3b. Geometry optimization properties of cis-xylomollin at $300 \mathrm{~K}$ with AMBER before MD simulations.

\begin{tabular}{|c|c|c|c|c|c|c|c|c|c|}
\hline \multirow[b]{2}{*}{ State } & \multicolumn{9}{|c|}{ Geometry } \\
\hline & $\begin{array}{c}\text { Bond } \\
(\mathrm{Kcal} / \mathrm{mol})\end{array}$ & $\begin{array}{c}\text { Angle } \\
(\mathrm{Kcal} / \mathrm{mol})\end{array}$ & $\begin{array}{c}\text { Dihedral } \\
\text { (Kcal/mol) }\end{array}$ & $\begin{array}{c}\text { VDW } \\
\text { (Kcal/mol) }\end{array}$ & $\begin{array}{c}\text { Stretch- } \\
\text { bend } \\
(\mathrm{Kcal} / \mathrm{mol})\end{array}$ & $\begin{array}{c}\text { H-bond } \\
(\mathrm{Kcal} / \mathrm{mol})\end{array}$ & $\begin{array}{c}\text { Electrostatic } \\
(\mathrm{Kcal} / \mathrm{mol})\end{array}$ & $\begin{array}{c}\text { Energy } \\
(\mathrm{Kcal} / \mathrm{mol})\end{array}$ & $\begin{array}{c}\text { Gradient } \\
\text { (Kcal/ } \\
\text { Å.mol) }\end{array}$ \\
\hline Isolated & 0.7699 & 5.0700 & 6.0819 & 3.0612 & - & -0.0003 & 0 & 14.9831 & 0.0966 \\
\hline Solvated & 0.7691 & 5.0558 & 6.0836 & 3.0681 & - & -0.0002 & 0 & 14.9767 & 0.0927 \\
\hline
\end{tabular}

In both environment, the minimum potential energies $E_{M D \text {,min }}$ calculated for the geometry optimization using AMBER are higher in trans- structure than in cis- (respectively $14.8 \mathrm{Kcal} / \mathrm{mol}$, and $10.47 \mathrm{Kcal} / \mathrm{mol}$ ). We note that the dihedral factor in potential energy is big in the trans- molecule than in the cis- one when using AMBER field (tables $4 \mathrm{a}, 4 \mathrm{~b}$ ). For the last situation, we think that the system considers the friction coefficient which affects the structure geometry of molecule in the cis form.

Variations are visible for angle, and dihedral energies. The much important difference is happened in the angle energies. The big value (angle energies) in the cis-structure is due to strong interactions between atoms and the values of angles (trans-: $\mathrm{C}_{4}-\mathrm{C}_{5}-\mathrm{C}_{9} 107.5^{\circ}, \mathrm{C}_{1}-\mathrm{C}_{9}-$ $\mathrm{C}_{5} 106.7^{\circ}$; cis-: $\mathrm{C}_{4}-\mathrm{C}_{5}-\mathrm{C}_{9} 113^{\circ}, \mathrm{C}_{1}-\mathrm{C}_{9}-\mathrm{C}_{5} 112^{\circ}$ ).

Table 4a. Geometry optimization properties of trans-xylomollin at $300 \mathrm{~K}$ with AMBER after MD simulations (in vacuum and in water).

\begin{tabular}{|c|c|c|c|c|c|c|c|c|c|}
\hline State & $\begin{array}{c}\text { Bond } \\
(\mathrm{Kcal} / \mathrm{mol})\end{array}$ & $\begin{array}{c}\text { Angle } \\
\text { (Kcal/mol) }\end{array}$ & $\begin{array}{c}\text { Dihedral } \\
\text { (Kcal/mol) }\end{array}$ & $\begin{array}{c}\text { VDW } \\
(\text { Kcal/mol) }\end{array}$ & $\begin{array}{l}\text { Stretch- } \\
\text { bend } \\
(\mathrm{Kcal} / \mathrm{mol})\end{array}$ & $\begin{array}{c}\text { H-bond } \\
(\mathrm{Kcal} / \mathrm{mol})\end{array}$ & $\begin{array}{c}\text { Electrostatic } \\
\text { (Kcal/mol) }\end{array}$ & $\begin{array}{c}\text { Energy } \\
(\mathrm{Kcal} / \mathrm{mol})\end{array}$ & $\begin{array}{c}\text { Gradient } \\
\text { (Kcal/ } \\
\text { Å.mol) }\end{array}$ \\
\hline Isolated & 0.5663 & 2.7598 & 8.5234 & 2.9413 & - & -0.0002 & 0 & 14.7907 & 0.0897 \\
\hline Solvated & 0.5899 & 2.84978 & 8.4689 & 2.9680 & - & -0.0002 & 0 & 14.8764 & 0.0996 \\
\hline
\end{tabular}

Table 4b. Geometry optimization properties of cis-xylomollin at $300 \mathrm{~K}$ with AMBER after MD simulations (in vacuum and in water).

\begin{tabular}{|c|c|c|c|c|c|c|c|c|}
\hline State & $\begin{array}{c}\text { Bond } \\
(\mathrm{Kcal} / \mathrm{mol})\end{array}$ & $\begin{array}{c}\text { Angle } \\
(\mathrm{Kcal} / \mathrm{mol})\end{array}$ & $\begin{array}{c}\text { Dihedral } \\
(\mathrm{Kcal} / \mathrm{mol})\end{array}$ & $\begin{array}{c}\text { VDW } \\
(\mathrm{Kcal} / \mathrm{mol})\end{array}$ & $\begin{array}{c}\text { Stretch- } \\
\text { bend } \\
(\mathrm{Kcal} / \mathrm{mol})\end{array}$ & $\begin{array}{c}\text { H-bond } \\
(\mathrm{Kcal} / \mathrm{mol})\end{array}$ & $\begin{array}{c}\text { Electrostatic } \\
(\mathrm{Kcal} / \mathrm{mol})\end{array}$ & $\begin{array}{c}\text { Energy } \\
(\mathrm{Kcal} / \mathrm{mol})\end{array}$ \\
\hline Isolated & 0.5235 & 4.1015 & $\mathbf{3 . 9 9 0 0}$ & 1.8550 & - & -0.0005 & 0 & $\mathbf{1 0 . 4 7 0 7}$ \\
\hline Solvated & 0.5795 & 4.3416 & $\mathbf{3 . 9 3 9 0}$ & 2.4038 & - & -0.0001 & 0.0908 \\
\hline
\end{tabular}




\section{2. Molecular Dynamic simulations}

Dynamic simulations were accomplished at constant temperature, using AMBER force field. The conjugate gradient (Polak-Ribiere) algorithm was preferred because for the constant dielectric. We have calculated the xylomollin (trans- and cis-) dynamic properties in both gas and water. We have employed the TIP3P water molecules model, and chosen the bath relaxation time equals to $0.1 \mathrm{ps}$. The simulation temperature was fixed to $300 \mathrm{~K}$ and the step at $20 \mathrm{~K}$. The run time was $0.5 \mathrm{ps}$, the step size was $0.0001 \mathrm{ps}$ and the heat time was $0.1 \mathrm{ps}$. Here, we study the evolution of: i) energies and ii) dihedrals angles in both vacuum and water environments for the two systems: trans- and cis-xylomollin.

At first, we have calculated all energies for the two systems then represented them in figures 4 and 5. The average energies are in good agreement with the simulation accuracy. The sampling results of step-size of MD method in vacuum and water are presented in figures (a) and (b), respectively.

For the trans-xylomollin, the total energies (ETOT) are the same in MD simulations in vacuum and water environments. After equilibration, the MD simulation becomes more stable (respectively $73.58 ; 75.48 \mathrm{Kcal} / \mathrm{mol}$ ). The potential energy (EPOT) and the kinetic energy (EKIN) illustrate fluctuations in both environment and vary around $(40.66,47.34) \mathrm{Kcal} / \mathrm{mol}$, and $(32.92,28.14) \mathrm{Kcal} / \mathrm{mol}$ (figures 4). In simulation, we observe that the trajectory of potential energy has attained a minimum around $0.4 \mathrm{ps}(30 \mathrm{Kcal} / \mathrm{mol})$. In the same time, the kinetic energy provides an opposite situation i.e. its reach a maximum $(43 \mathrm{Kcal} / \mathrm{mol})$.

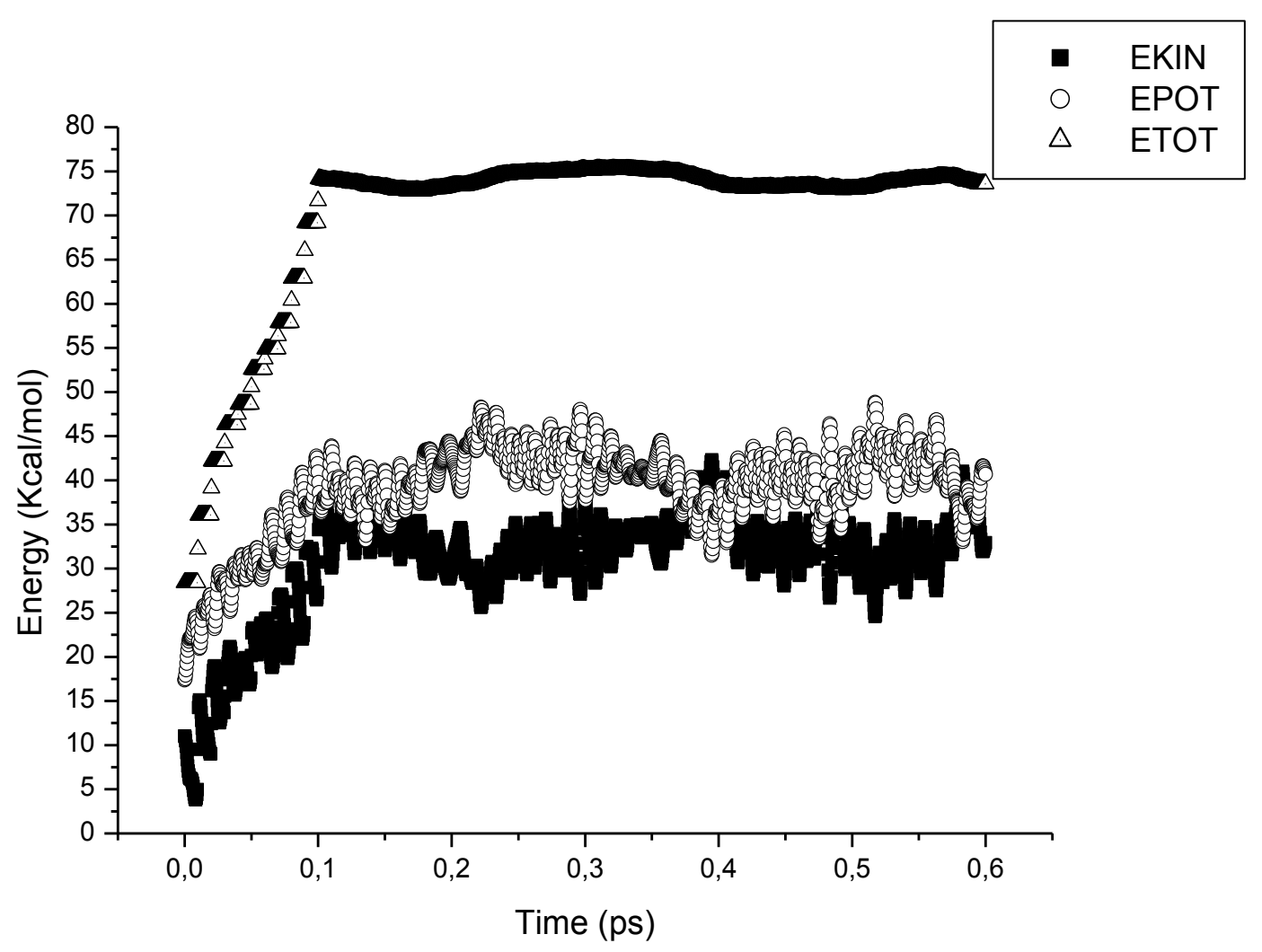

(a) 


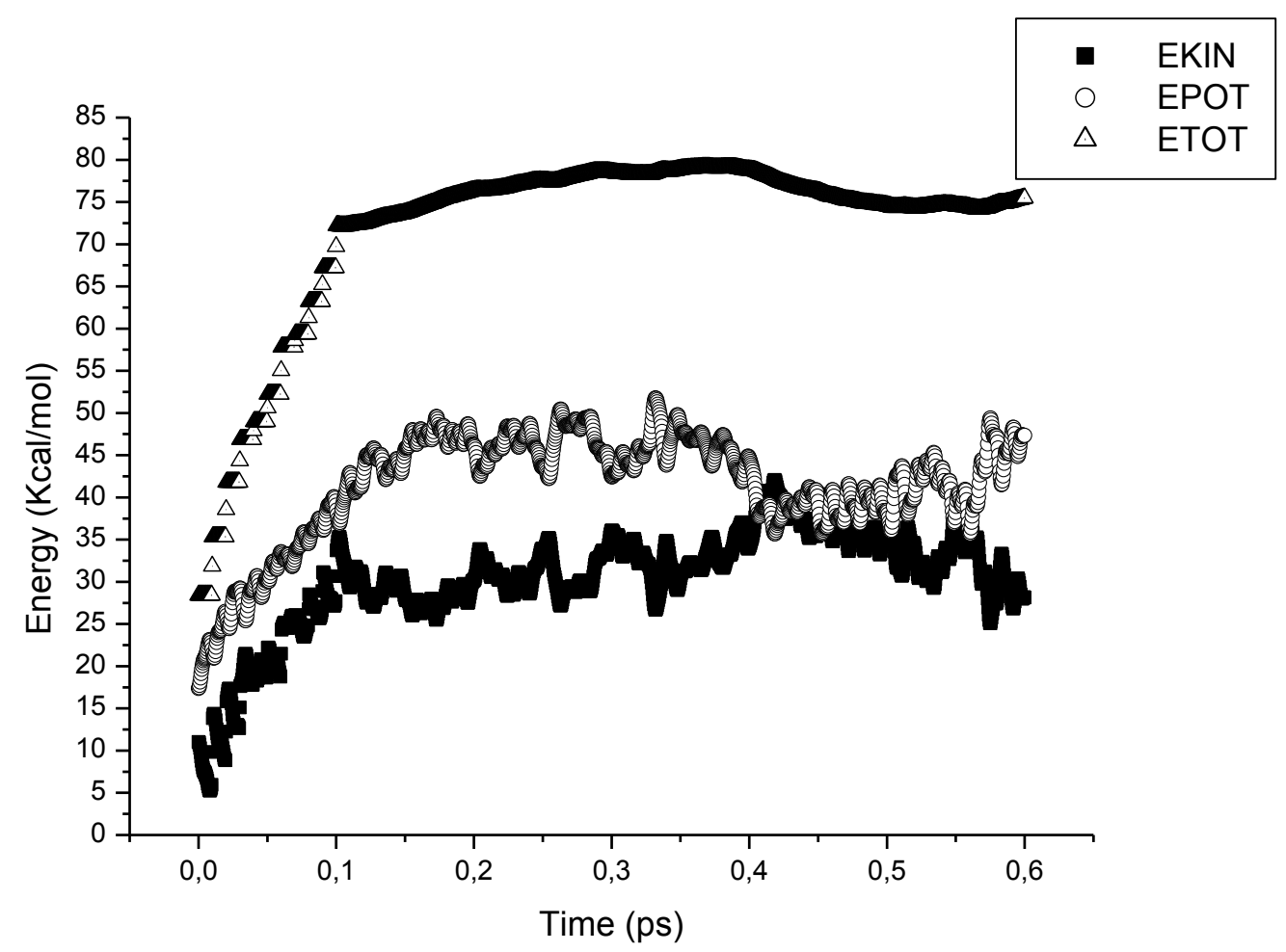

(b)

Fig.4. Evolution of energies for trans-xylomollin with AMBER: (a) in vacuum, (b) in water.

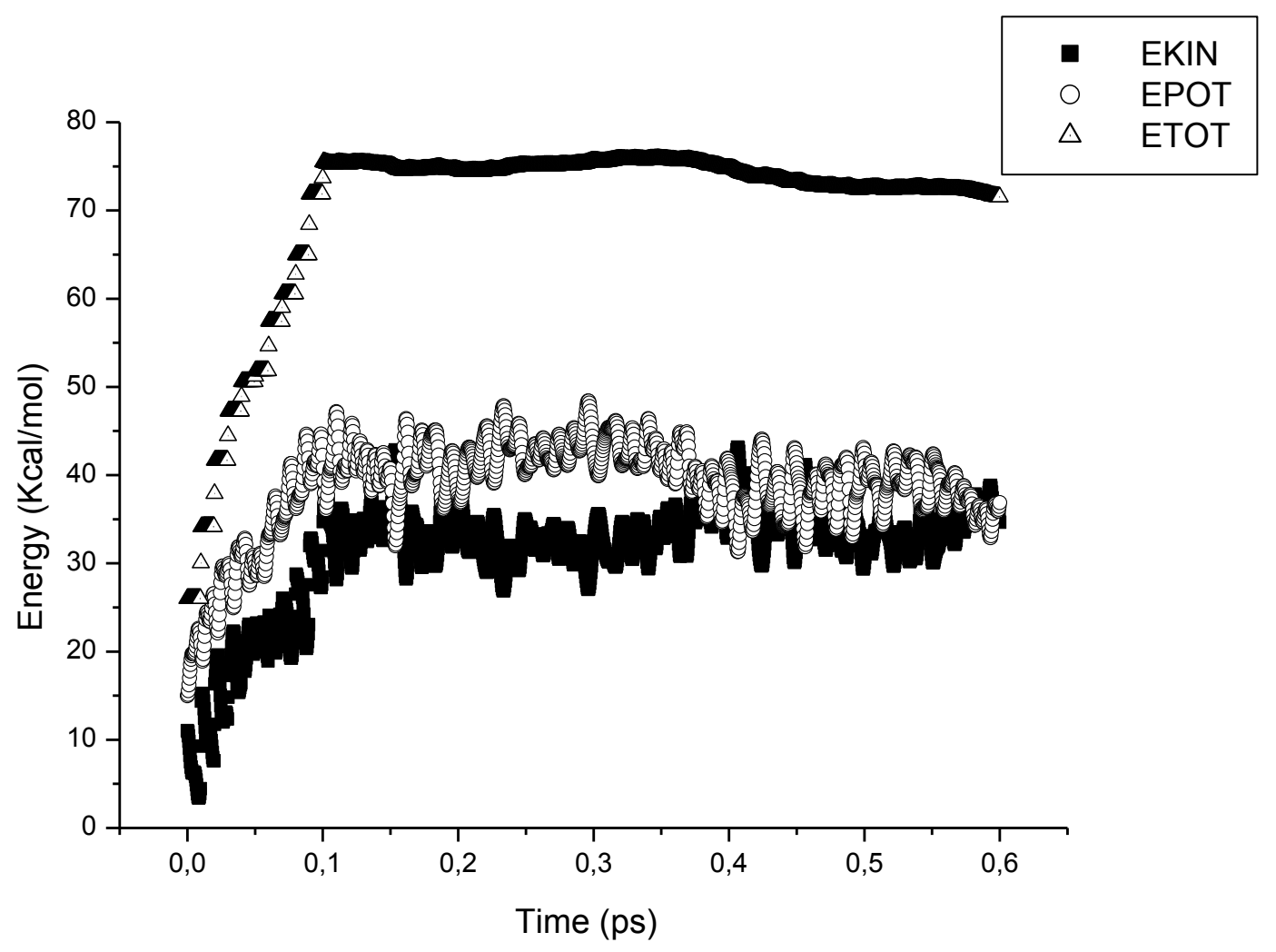

(a) 


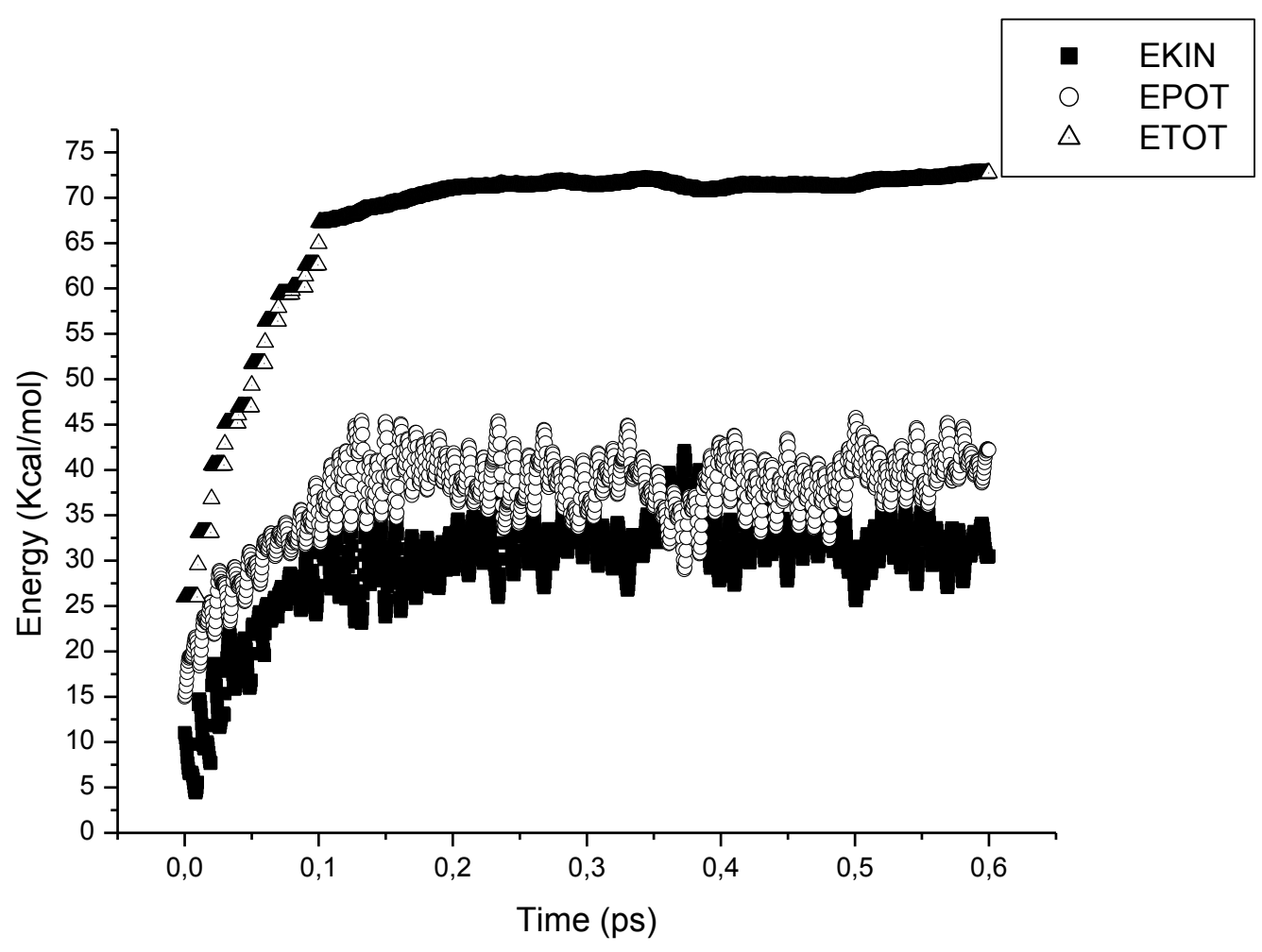

(b)

Fig. 5. Evolution of energies for cis-xylomollin with AMBER: (a) in vacuum, (b) in water.

For the cis-xylomollin, the positions of all energies stay unaltered (vacuum: ETOT 71.53, EKIN 34.65, EPOT $36.88 \mathrm{Kcal} / \mathrm{mol}$; water: ETOT 72.72, EKIN 30.50, EPOT 42.21, $\mathrm{Kcal} / \mathrm{mol}$ ). All energies are very stables at time greater than $0.1 \mathrm{ps}$ for both environments. Here, the fluctuations disappear in spite of weak interactions between molecules. We note the same situation around 0.4 ps i.e. the potential energy has attained a minimum at $30 \mathrm{Kcal} / \mathrm{mol}$, and in the same time, the kinetic energy provides the opposite situation and reaches a maximum at $43 \mathrm{Kcal} / \mathrm{mol}$.

Comparing the results for the two systems, we note that the total and potential energies obtained for the trans- structure are lightly up to those obtained for the cis- form. The situation is opposite for kinetic energies. So, here the potential energies correspond to the configuration energies for each diastereoisomer.

Both configuration isomers (trans- and cis-) are influenced by the same effects: stereoelectronic and anomeric. The trans- molecule forbids the tiling of conformation and the structure adopts the stiff form. So, the steric hindrance effect between the two protons $\mathrm{H}_{37}$ and $\mathrm{H}_{29}$ is less and their non-bonded distance is high $(3.0 \AA)$. For the cis-molecule, the junction $\left(\mathrm{C}_{5}-\mathrm{C}_{9}\right)$ of the two cycles allows the possibility to till between two chair forms. So, this structure is flexible. As consequence, the two protons $\mathrm{H}_{37}$ and $\mathrm{H}_{29}$ are carried by the concave face and their non-bonded distance $(2.3 \AA)$ is less than VDW radius $(2.4 \AA)$. We conclude that our Molecular Dynamics is suitable for the two systems, our MD results are in harmony with the coupling constant found in literature (trans-: ${ }^{3} J_{\mathrm{H} 37 \mathrm{H} 29}=10 \mathrm{~Hz}$ ), and converge to the much stable compound: the trans-xylomollin ( $\mathrm{E}_{\text {config trans- }}>\mathrm{E}_{\text {config } \text { cis- }}$ ).

After analyze the evolution of values of dihedrals angles $\mathrm{H}_{37}-\mathrm{C}_{5}-\mathrm{C}_{9}-\mathrm{H}_{29}$ for transxylomollin, we have observed that the angle is instable in MD simulation in gas. During this simulation run, the torsion angle oscillates between multiple states. The deviation has two 
states of stability: the first until 0.07 ps. The second state has about fully duration of the simulation run in MD calculations (figure 6).

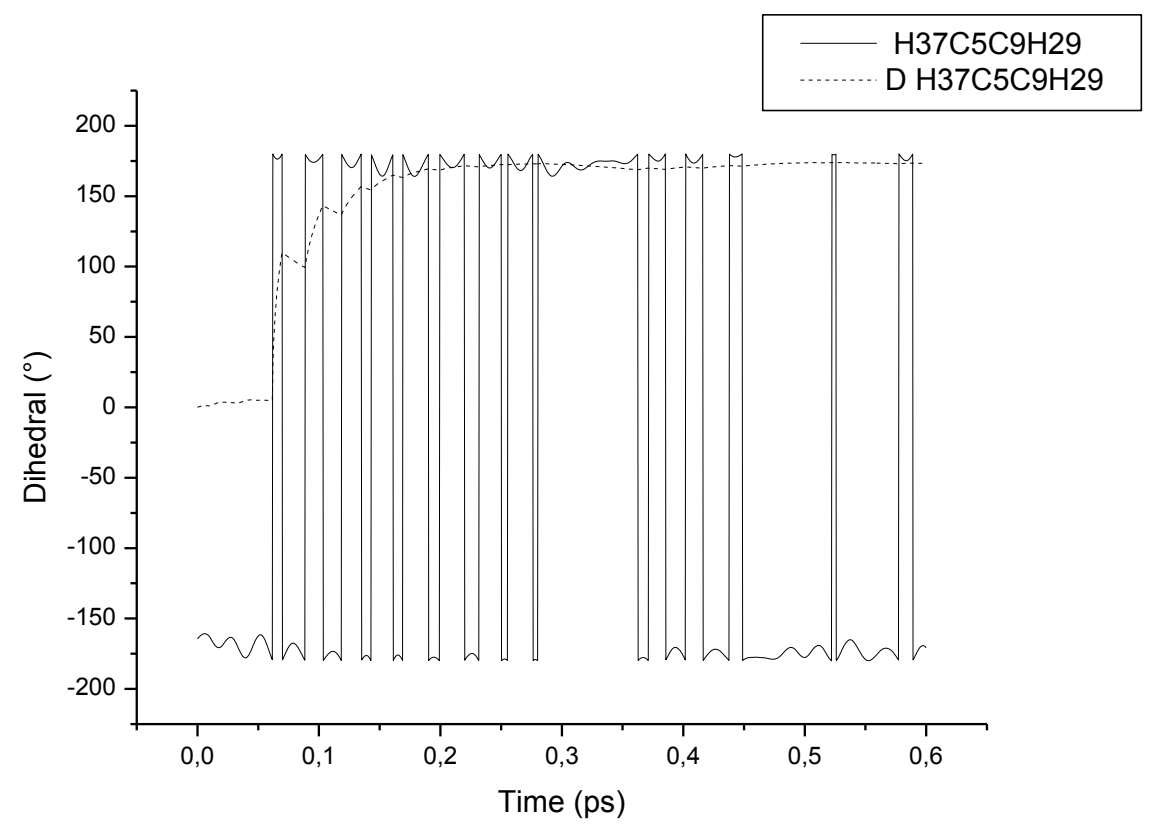

(a)

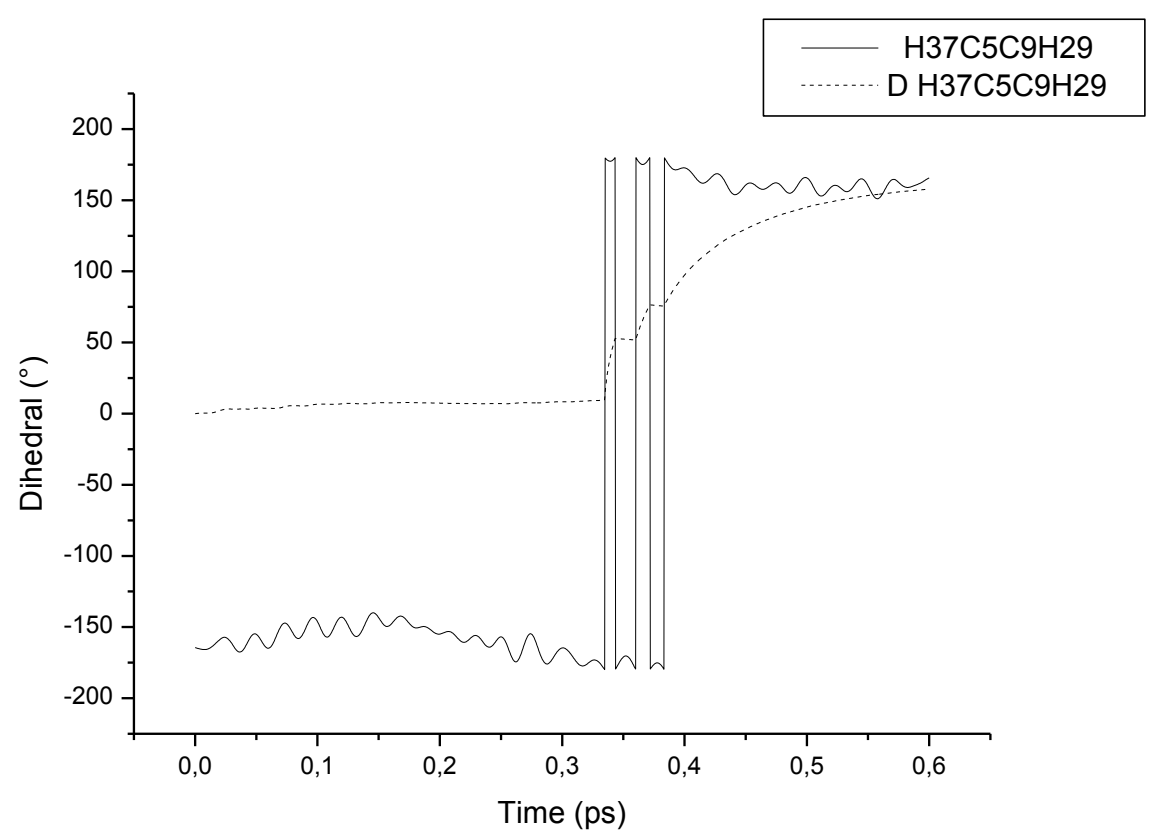

(b)

Fig. 6. Evolution of dihedral angles for trans-xylomollin with AMBER: (a) in vacuum, (b) in water.

In water, the dihedral angle and its deviation present two phases of stability (first at $0.34 \mathrm{ps}$, second at $0.39 \mathrm{ps}$ ) which are separate by short periods in which torsion angle turns quickly into an anhedral angle (two states) (figure 6). Finally, the angle becomes stable and gets a value of dihedral angle which correspond a trans- configuration. So, we confirm that our trans-system is more stable in water than in gas. 
For the cis-xylomollin, the dihedral curves are similar in the two environments. The dihedral angles are most anhedral, present instability, and oscillate between multiple states. So, this molecule undergoes tilting of conformation because of the cis- cycle junction (figure7). From these results, we confirm that the molecule carries an intermediary conformer structures imposed by the concave face of $\mathrm{C}_{5}-\mathrm{C}_{9}$ bond.

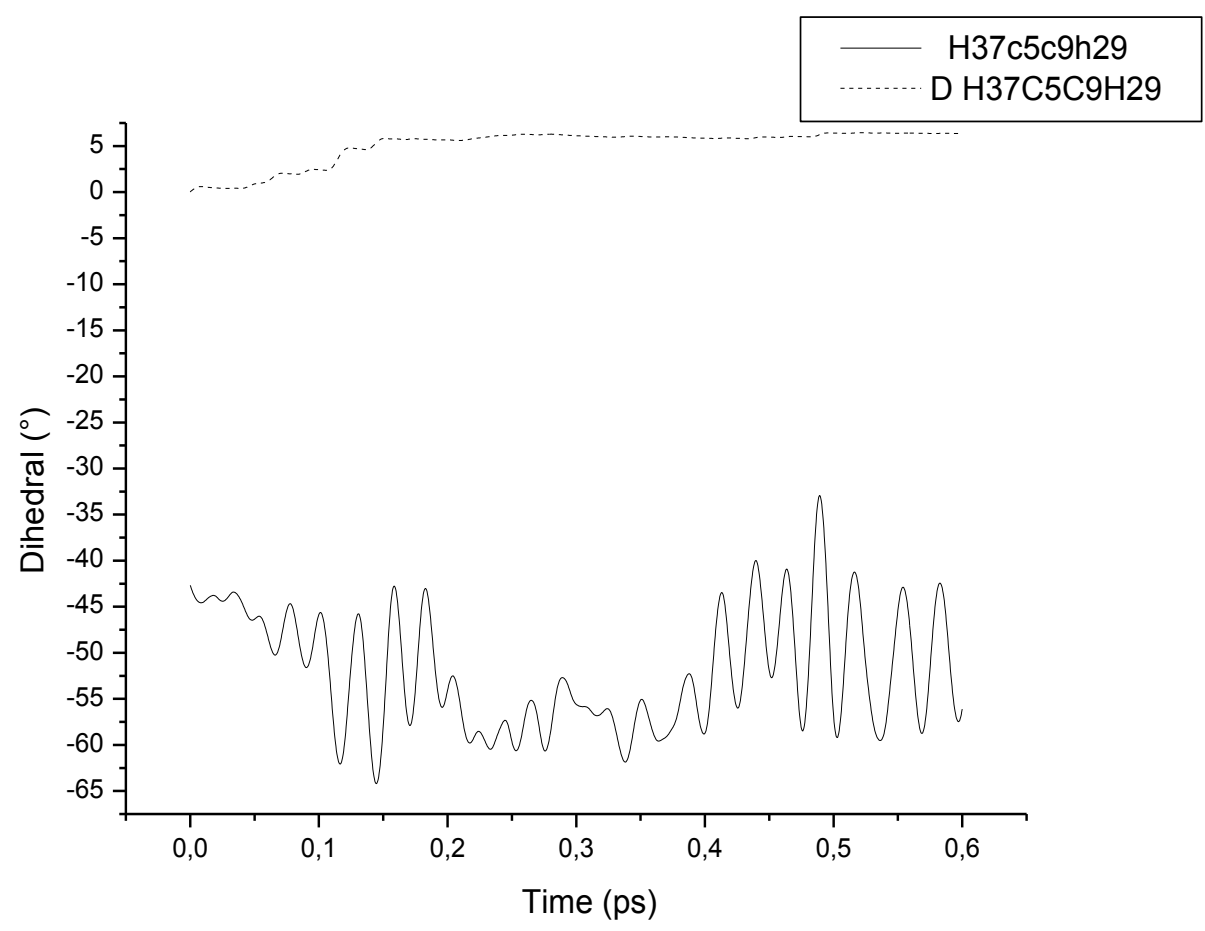

(a)

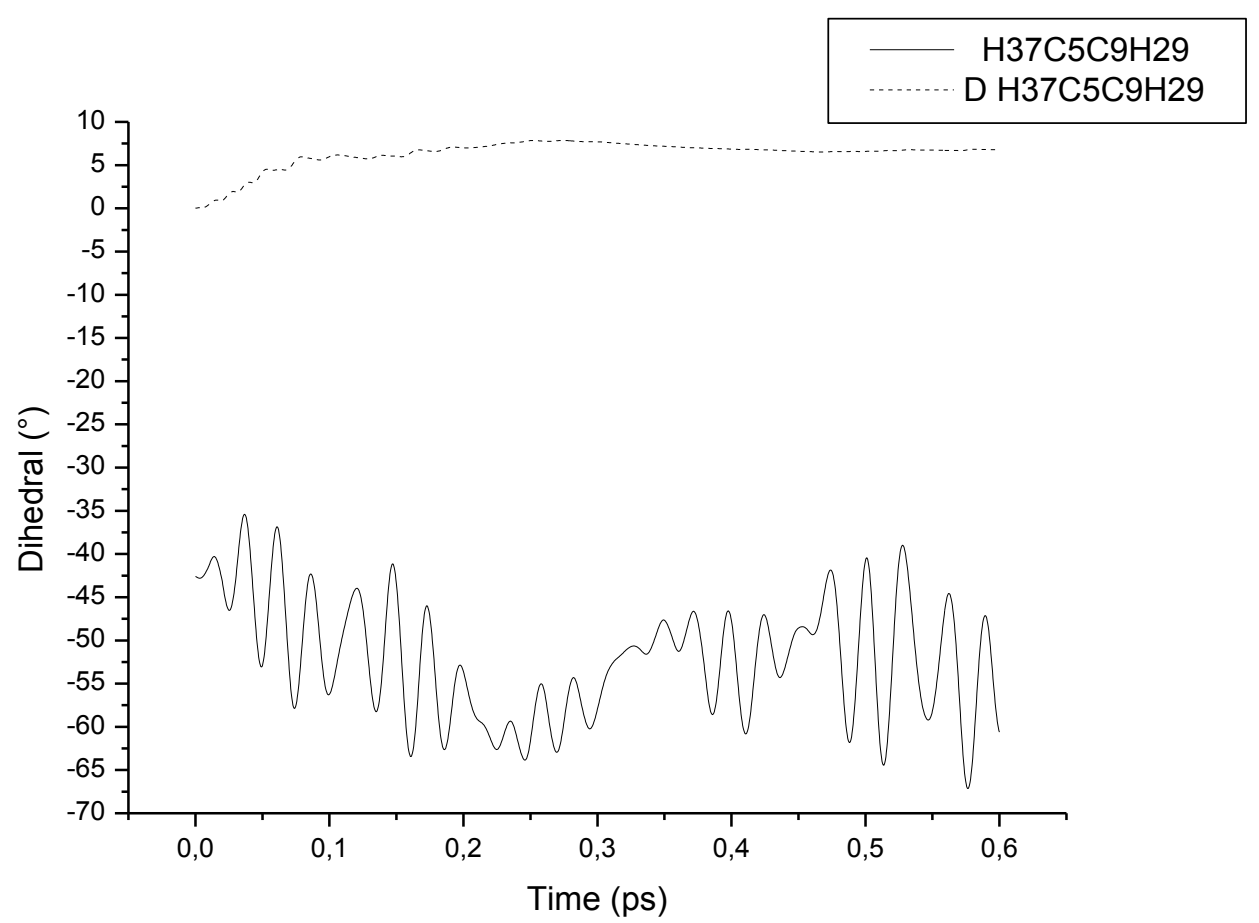

(b)

Fig. 7. Evolution of dihedral angles for cis-xylomollin with AMBER: (a) in vacuum, (b) in water. 
In the actual conditions, the torsion angles seem into anhedral angle for all simulations. Consequently, deviations have an important state of stability while the angle has been affected by the collision. The effect is well represented under AMBER field. So, the structure has been disturbed while the calculation runs. At this transition period, the cisconfiguration geometry is conserved.

The differences will appear for both configurations (trans-, cis-) and under the same field (AMBER) where the angle changes in these simulations due to the interaction molecule structures. As consequence, we conclude that our trans-system is more stable than the cis one principally in water.

\section{CONCLUSIONS}

We have essentially studied the two bridgehead $\mathrm{H}_{5}$ and $\mathrm{H}_{9}$ configurations (trans and cis) using simulation calculations in order to establish the much stable configuration in the bicyclic structure. So, we have studied the evolution of the geometry optimized properties for the trans- and cis- xylomollins. We have chosen the MD method to predict much better the characteristics. The geometries, interaction energies, bonds, angles, dihedrals and the VDW interactions were carried out in solution and in gas phase. We have calculated the thermodynamic and structural properties for the two configurations with AMBER force field. Then, we have compared these results with those of literature in order to confirm the stable structure.

The energies are stable in MD simulations under the AMBER field. In water, we note that the total and potential energies obtained for the trans- structure are lightly up to those obtained for the cis- form. In gas, the situation is similar. We conclude that our Molecular Dynamic method is suitable for the xylomollin systems, and gives good results for the transmolecule.

At a short period, the torsion angle changes due to the interaction of water molecules and turns quickly into dihedral angle. During the simulation time, the trans- molecule conserve its configuration geometry, adopts the stiff form, and forbids the steric hindrance effect between the two protons $\mathrm{H}_{37}$ and $\mathrm{H}_{29}$.

We conclude that our simulation under AMBER field gives best results; the transxylomollin acquires the configuration energy. So, the trans-molecule reaches its high stable configuration state in solution environment under AMBER field. Our MD simulation results are good and in agreement with those of NMR data literature.

\section{REFERENCES}

[1] Bandaranayake W. M., Wetlands Ecology. Manag. 10(6) (2002) 421-452.

[2] Akcos Y., Ezer N., Ozcelik B., Abbasoglu U., Farm. Bilimler Derg. 23 (1998) 99-103.

[3] Baruah, C. C., Gupta P. P., Amar Nath, Patnaik Late G. K., Dhawan B. N., Pharmacol. Res. 38(6) (1998) 487-492.

[4] Owen R. W., Mier W., Giacosa A., Hull W. E., Spiegelhalder B., Bartsch H., Food. Chem. Toxicol. 38(8) (2000) 647-659.

[5] Cuendet M., Potterat O., Hostettmann K., Pharma. Biol. 37(4) (1999) 318-320.

[6] Bowers M. D., Puttick G. M., J. Chem. Ecol. 14 (1988) 319-334. 
[7] Zeyheri H., Baghdikian B., Lanhers M.C., Fleurentin J., Ollivier E., Millard C., Balansard G., Mortier F., Planta Med. 63(2) (1997) 171-176.

[8] Mathad V. T., Raj K., Badhuri A. P., Sahai R., Puri A., Tripathi L. M., Strivastava V. L. M., Bioorg. Med. Chem. 6(5) (1998) 605-611.

[9] Mandal S., Jain R., Mukhopadhyay S., Indian J. Pharm. Sci. 60(3) (1998) 123-127.

[10] Fleming H. P., Walter W. M., Etchells J. L., Appl. Microbiol. 26(5) (1973) 777-782.

[11] Kubo I., Matsumoto A., Takase I., J. Chem. Ecol. 11(2) (1985) 251-263.

[12] Yamano T., Tsujimoto Y., Noda T., Shimizu M., Ohmori M., Morita S., Yamada A., Food. Chem. Toxicol. 28(7) (1990) 515-519.

[13] Cervellati R., Speroni E., Govoni P., Guerra M. C., Costa S., Arnold U. W., Stuppner, H., Z. Naturforsch C. 59(3-4) (2004) 255-562.

[14] Jeong E. J., Lee K. Y., Kim S.H., Sung S. H., Kim Y. C., Eur. J. Pharmacol. 588(1) (2008) 78-84.

[15] Bhandari P., Kumar N., Singh B., Ahuja P. S., Indian J. Exp. Biol. 48(3) (2010) 323-328.

[16] Sang S., He K., Liu G., Zhu N., Cheng X., Wang M., Zheng Q., Dong Z., Ghai G., Rosen R. T., Ho C., Org. Lett. 3 (2001) 1307

[17] Bouyssi D., Monteiro N., Balme G., Tetrahedron Lett. 40 (1999) 1297-1300.

[18] Whitesell J.K., Wang P. K. S., Aguilar D. A., J. Org. Chem. 48 (1983) 2511-2515.

[19] Nakane M., Hutchinson C. R., VanEngen D., Clardy J., J. Am. Chem. Soc. 100 (1978) 7079-7080.

[20] Plouvier V., Favre-Bonvin J., Phytochem. 10(8) (1971) 1697-1722.

[21] Eliel E., Stereochemistry of Carbon Compounds, McGraw-Hill., New York, (1962) P.279.

[22] Whitesell J. K., Wang P. K. S., Aguilar D. A., 175th National Meeting of the American Chemical Society, Anaheim, Calf, March13-14, 1978.

[23] Hassam S. B., Hutchinson C.R., Tetrahedron Lett. 21(13) (1980) 1209-1212.

[24] Kubo I., Miura I., Nakanishi K., J. Am. Chem. Soc. 98(21) (1976) 6704-6705.

[25] Krull R. E., Stermitz F. R., Franzyk H., Rosendal Jensen S., Phytochem. 49(6) (1998) 1605-1608.

[26] Foderaro T. A., Stermitz F. R., Hope H., Tetrahedron Lett. 33 (1992) 2953-2954.

[27] Karioti A., Chatzopoulou A., Bilia A. R., Liakopoulos G., Stavrianakou S., Skaltsa H., Biosci. Biotechnol. Biochem. 70(8) (2006) 1898-1903. 